\title{
The Brachyura (Crustacea, Decapoda) of the coast of the State of Paraíba Brazil, collected by Project Algas
}

\author{
Gustavo A. S. de Melo ${ }^{1} \&$ Valéria G. Veloso ${ }^{2}$ \\ ${ }^{1}$ Museu de Zoologia, Universidade de São Paulo. Caixa Postal 42594, 04299-970 São Paulo, São Paulo, Brasil. \\ Bolsista do CNPq. E-mail: gasmelo@usp.br \\ ${ }^{2}$ Departamento de Ciências Naturais, Universidade Federal do Estado do Rio de Janeiro. Avenida Pasteur 458, Urca, \\ 22290-240 Rio de Janeiro, Rio de Janeiro, Brasil. E-mail: vgveloso@osite.com.br
}

\begin{abstract}
A survey was made of the species of Brachyura collected by "Project Algas", along the entire coast of the state of Paraíba, Brazil. This project was one of the most complete ever carried out off the coast of this state. At the 93 stations sampled by the vessel "Pesquisador IV", 60 species, in 41 genera and 15 families were collected. For each species, the geographical distribution, habitat and list of stations where it occurred are given. Also provided are a map showing the locations of all the project stations and a table with the oceanographic data of each station and the species occurring at each station.
\end{abstract}

KEY WORDS. Crabs, survey, littoral, Northeastern Brazil.

RESUMO. Os Brachyura (Crustacea, Decapoda) da costa do estado da Paraíba, Brasil, coletados pelo Projeto Algas. Foi elaborado um levantamento faunístico das espécies de Brachyura coletadas pelo "Projeto Algas", ao longo de todo o litoral do estado da Paraíba, Brasil. Este projeto foi um dos mais completos já efetuados no litoral desse Estado. Nas 93 estações feitas pelo barco “Pesquisador IV” foram coletadas 60 espécies, incluídas em 41 gêneros e 15 famílias. Para cada espécie são fornecidas informações sobre: distribuição geográfica, habitat e lista das estações em que ocorreram. São fornecidos, também, um mapa com a localização de todas as estações do projeto e uma tabela com os dados oceanográficos de cada estação e com as espécies que ocorreram em cada estação.

PALAVRAS CHAVE. Caranguejos, levantamento, litoral, Nordeste brasileiro

In order to locate algal banks of economic importance along the coast of Paraíba, the Division of Fishery Resources of the Superintendency of Development of the Northeast (Divisão de Recursos Pesqueiros da Superintendência do Desenvolvimento do Nordeste, SUDENE) developed "Projeto Algas" (Project Algae). Along the $130 \mathrm{~km}$-long Paraiban coast, survey cruises were made between January and June 1981. During this period, samples were obtained from 93 stations, at depths from 10 to 35 $\mathrm{m}$, located along 23 profiles perpendicular to the coastline. The stations began off the mouth of the Goiana River, the boundary with the state of Pernambuco $\left(07^{\circ} 33^{\prime} \mathrm{S}, 34^{\circ} 59^{\prime} \mathrm{W}\right)$, and continued to the boundary of the state of Rio Grande do Norte $\left(06^{\circ} 26^{\prime} \mathrm{S}\right.$, $34^{\circ} 52^{\prime} \mathrm{W}$ ), where the last stations were located (Fig. 1).

Of the 93 project stations, $3(24,25,26)$ were not sampled, and at 12 stations $(14,17,41,44,58,59,70,72,78,79,91,92)$ no brachyurans were collected.

The biological material collected by the vessel "Pesquisador IV" was sorted, identified and deposited in the Department of Sistematics and Ecology of the Universidade Federal da Paraíba (DSE) and in the Museu de Zoologia da Universidade de São Paulo (MZUSP). This material constitutes an important resource for studies of the marine fauna of this state, in which there are almost no previous studies of the composition of the marine species in this region.

Classification of the species, genera and families was based on Melo (1996) and Martin \& Davis (2001). The Xanthidae was an exception, because according to MARTIN \& DAVIS (2001: 53) this group is in need of a thorough taxonomic as well as phylogenetic revision; there is no general agreement as to which genera should be included in which families. For this reason, in the present work all the genera and species of this group were included in the old family Xanthidae s.l.

\section{RESULTS \\ Dromiidae De Haan, 1833}

\section{Moreiradromia antillensis (Stimpson, 1858)}

Distribution: Western Atlantic - North Carolina, Bermuda, Florida, Gulf of Mexico, Antilles, Venezuela, Guiana, Suriname, French Guiana and Brazil (from Amapá to Rio Grande do Sul).

Habitat: Hard substrates such as corals, broken shells and rocks. Intertidal to $330 \mathrm{~m}$. They generally cover the carapace with sponges or ascidians. 


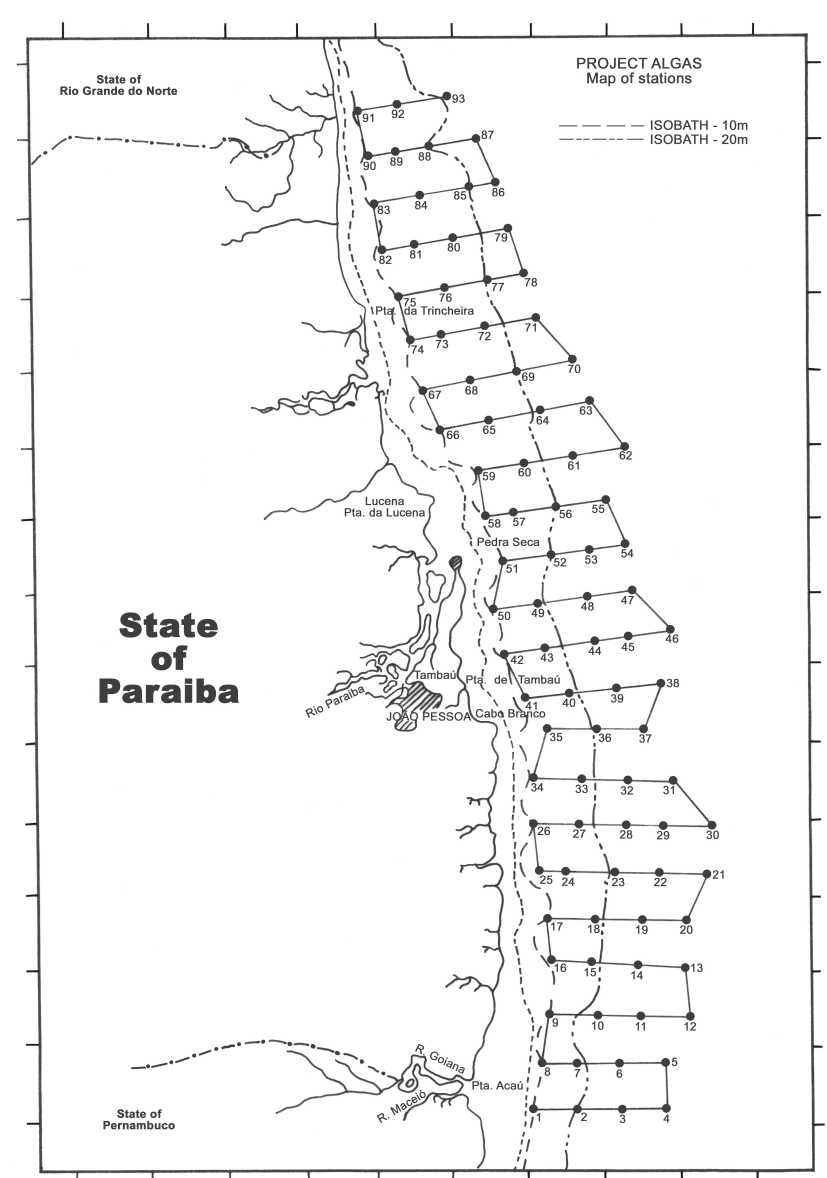

Figura 1. Map of stations of the Project Algas.

Material examined: Stations 30, 53, 88.

Remarks: Moreiradromia antillensis is a new combination for Cryptodromiopsis antillensis, a relatively common species along the Brazilian coast (see GuINot \& TAVAREs 2003: 82).

\section{Dorippidae De Haan, 1838}

\section{Ethusa americana A. Milne-Edwards, 1880}

Distribution: Western Atlantic - North Carolina, Florida, Gulf of Mexico, Antilles and Brazil (from Maranhão to Rio de Janeiro). Eastern Pacific - Gulf of California and (?) Panama.

Habitat: Rock and coral bottoms, sand and shell substrates; also on bottoms with algae and bryozoans. Shallow waters to $90 \mathrm{~m}$.

Material examined: Station 53.

\section{Raninidae De Haan, 1839}

\section{Symethis variolosa (Fabricius, 1793)}

Distribution: Western Atlantic - North Carolina, Florida, Gulf of Mexico, Antilles and Brazil (Fernando de Noronha, and from Amapá to São Paulo).

Habitat: Sand, mud and calcareous algae bottoms. Depths from 20 to $110 \mathrm{~m}$.

Material examined: Stations 2, 3, 6, 7, 16, 29, 36, 37, 38, $43,45,47,80,85$.

\section{Calappidae H. Milne Edwards, 1837}

\section{Calappa gallus (Herbst, 1803)}

Distribution: Western Atlantic - Bermuda, Florida, Gulf of Mexico, Antilles, Central America, northern South America and Brazil (from Ceará to Rio Grande do Sul). Mid-Atlantic Santa Helena Island. Eastern Atlantic - Cape Verde islands to Angola. Indo-Pacific - Red Sea, Persian Gulf and Japan.

Habitat: Hard substrates such as corals, shells or rocks. Occasionally on calcareous algae and sand. Intertidal to $220 \mathrm{~m}$.

Material examined: Stations 12, 29, 31, 32, 33, 64.

\section{Calappa ocellata Holthuis, 1958}

Distribution: Western Atlantic - North Carolina, Florida, Gulf of Mexico, Antilles, Colombia, Venezuela and Brazil (from Amapá to Rio de Janeiro).

Habitat: Mud, sand, gravel or rock bottoms. Depths to $80 \mathrm{~m}$.

Material examined: Stations 4, 31.

\section{Calappa tortugae Rathbun, 1933}

Distribution: Western Atlantic - North Carolina, Florida, Gulf of Mexico, Antilles, Venezuela and Brazil (from Paraíba to Rio Grande do Sul).

Habitat: On substrates of sand, broken shells, corals and gravel. Shallow waters to $280 \mathrm{~m}$, but preferentially between 7 and $50 \mathrm{~m}$.

Material examined: Stations 61, 82.

Remarks: Calappa tortugae Rathbun, 1933 is a senior synonym for C. angusta A. Milne Edwards, 1880 (see Williams \& CHILD 1988: 109).

\section{Cryptosoma balguerii (Desbonne, 1867)}

Distribution: Western Atlantic - North Carolina, Bermuda, Florida, Gulf of Mexico, Antilles, Colombia, Venezuela and Brazil (from Amapá to Rio de Janeiro).

Habitat: Bottoms of sand, mud, corals and shell gravel. Sublittoral to $230 \mathrm{~m}$.

Material examined: Station 2.

Remarks: Cryptosoma balguerii (Desbonne, 1867) is a new name for Cycloes bairdii Stimpson, 1860, a species widely found along the Brazilian coast (see GALIL \& CLARK 1996: 186).

\section{Leucosiidae Samouelle, 1819}

\section{Ebalia stimpsoni A. Milne-Edwards, 1880}

Distribution: Western Atlantic - North Carolina, Florida, Gulf of Mexico, Antilles, Colombia and Brazil (from Amapá to São Paulo).

Habitat: Mud-sand, broken-shell and coral bottoms. Shallow waters to $160 \mathrm{~m}$. 
Material examined: Stations 47, 82.

\section{Iliacantha sparsa Stimpson, 1871}

Distribution: Western Atlantic - Florida, Gulf of Mexico, Antilles, Colombia and Brazil (from Pará to Espírito Santo).

Habitat: Gravel, shell, coral and calcareous-algae bottoms. Depths between 20 and $80 \mathrm{~m}$.

Material examined: Stations 37, 56.

Lithadia brasiliensis (von Martens, 1872) Paulo).

Distribution: Western Atlantic - Brazil (from Pará to São

Habitat: Sand, gravel and occasionally mud bottoms. Shallow waters to $40 \mathrm{~m}$.

Material examined: Stations 76, 85.

Lithadia vertiginosa (Coelho, 1973)

Distribution: Western Atlantic - Brazil (banks off the Ceará coast, and from Pará to Bahia).

Habitat: Sandy, muddy and, mainly, calcareous algae bottoms. Depths between 30 and $60 \mathrm{~m}$.

Material examined: Station 62.

\section{Persephona punctata (Linnaeus, 1758)}

Distribution: Western Atlantic - Antilles, Colombia, Venezuela, Guianas and Brazil (from Amapá to Rio Grande do Sul).

Habitat: Sandy, shell and, mainly, muddy bottoms. Intertidal to $50 \mathrm{~m}$.

Material examined: Station 56.

\section{Speloeophorus elevatus Rathbun, 1898}

Distribution: Western Atlantic - Florida, Gulf of Mexico, Antilles and Brazil (from Maranhão to Bahia). to $85 \mathrm{~m}$.

Habitat: Preference for broken-shell bottoms and depths

Material examined: Stations 11, 33, 61.

\section{Speloeophorus nodosus (Bell, 1855)}

Distribution: Western Atlantic - North and South Carolina, Florida, Gulf of Mexico, Antilles and Brazil (from Maranhão to Rio de Janeiro).

Habitat: Sandy bottoms, between 10 and $30 \mathrm{~m}$.

Material examined: Stations 47, 76, 85

\section{Epialtidae MacLeay, 1838}

\section{Acanthonyx dissimulatus Coelho, 1991-93}

Distribution: Western Atlantic - Brazil (from Piauí to Bahia).

Habitat: Rocky, sandy, and algae-covered bottoms. Intertidal to $25 \mathrm{~m}$.

Material examined: Stations 18, 51, 76, 81, 90.

\section{Epialtoides rostratus Coelho, 1972}

Distribution: Western Atlantic - Brazil (from Maranhão to Espírito Santo).

Habitat: Bottoms of calcareous algae. Depths from 20 to $60 \mathrm{~m}$.
Material examined: Station 56.

\section{Epialtus bituberculatus $\mathrm{H}$. Milne Edwards, 1834}

Distribution: Western Atlantic - Florida, Gulf of Mexico, Antilles, Colombia, Venezuela and Brazil (from Ceará to São Paulo).

Habitat: Among algae in shallow waters. Also on hard bottoms and in tidepools.

Material examined: Station 74.

\section{Inachidae MacLeay, 1838}

\section{Aepinus septemspinosus (A. Milne-Edwards, 1879)}

Distribution: Western Atlantic - Florida, Gulf of Mexico, Antilles and Brazil (Fernando de Noronha and Rocas Atoll, and from Pará to São Paulo).

Habitat: Hard bottoms, mainly corals, rocks and calcareous algae. From 10 to $85 \mathrm{~m}$.

Material examined: Stations 48, 52, 53, 60.

\section{Podochela algicola (Stebbing, 1914)}

Distribution: Western Atlantic - Colombia and Brazil (from Maranhão to São Paulo).

Habitat: Sandy or calcareous algae substrates, protected among algae. Body completely camouflaged with pieces of algae between the setae of the ambulatory legs and the carapace. Between 25 and $90 \mathrm{~m}$.

Material examined: Stations 33, 45, 46, 53.

\section{Podochela brasiliensis Coelho, 1972}

Distribution: Western Atlantic - Brazil (from Ceará to Sergipe)

Habitat: Bottoms of calcareous algae. Depths between 20 and $50 \mathrm{~m}$.

Material examined: Stations 12, 57, 67.

\section{Podochela gracilipes Stimpson, 1871}

Distribution: Western Atlantic - North and South Carolina, Florida, Gulf of Mexico, Antilles, Colombia, Guianas and Brazil (from Amapá to Rio Grande do Sul).

Habitat: Sandy, gravel, broken-shell, rocky and coral bottoms. Intertidal to $220 \mathrm{~m}$. Carapace usually covered with pieces of algae.

Material examined: Stations 42, 50.

\section{Podochela riisei Stimpson, 1860}

Distribution: Western Atlantic - from North Carolina to the Gulf of Mexico, Antilles and Brazil (Paraíba, Pernambuco and Rio de Janeiro).

Habitat: On calcareous algae, sandy bottoms, and hard bottoms. Shallow waters to $140 \mathrm{~m}$.

Material examined: Stations 18, 45, 75, 76, 85.

\section{Inachoididae Dana, 1851}

Euprognatha acuta A. Milne Edwards, 1880

Distribution: Western Atlantic - Massachusetts to Florida, 
Gulf of Mexico, Antilles, Guianas, Brazil (from Amapá to Rio Grande do Sul) and Uruguay.

Habitat: Sandy, coral or shell bottoms. Shallow waters to considerable depths $(710 \mathrm{~m})$.

Material examined: Station 60.

\section{Mithracidae Balss, 1929}

\section{Leptopisa setirostris (Stimpson, 1871)}

Distribution: Western Atlantic - Florida, Antilles, Venezuela and Brazil (from Maranhão to Espírito Santo).

Habitat: Intertidal to $80 \mathrm{~m}$. On broken-shell, mud and, also, on bottoms with macro-algae. Young specimens are found in sponges.

Material examined: Stations 12, 29, 47, 89.

\section{Macrocoeloma laevigatum (Stimpson, 1860)}

Distribution: Western Atlantic - Florida, Gulf of Mexico, Antilles and Brazil (from Pará to Alagoas).

Habitat: Intertidal to $30 \mathrm{~m}$. Hard bottoms and on sand, often on bottoms with algae.

Material examined: Stations 27, 33, 34, 35, 36, 37, 56, 67, 75, 85, 88, 89, 90 .

\section{Macrocoeloma septemspinosum (Stimpson, 1871)}

Distribution: Western Atlantic - South Carolina, Florida, Gulf of Mexico and Brazil (from Ceará to Bahia).

Habitat: Substrates of sand, shell, coral and calcareous algae. Shallow waters to $145 \mathrm{~m}$ (rarely to $200 \mathrm{~m}$ ).

Material examined: Stations 2, 3, 54, 85.

\section{Macrocoeloma trispinosum (Latreille, 1825)}

Distribution: Western Atlantic - North Carolina, Bermuda, Florida, Gulf of Mexico, Antilles and Brazil (Fernando de Noronha, and from Piauí to São Paulo).

Habitat: Sandy, rocky and broken-shell bottoms, and in Sargassum. Shallow waters to $80 \mathrm{~m}$.

Material examined: Stations 12, 86.

\section{Microphrys antillensis Rathbun, 1920}

Distribution: Western Atlantic - North Carolina, Florida, Gulf of Mexico, Antilles and Brazil (from Paraíba to Rio de Janeiro).

Habitat: Sandy, muddy, coral and broken-shell bottoms, and living among algae. Shallow waters to $40 \mathrm{~m}$.

Material examined: Stations 5, 20, 21, 31, 32, 33, 35, 38, 39, 53, 60, 61, 65, 68, 69, 76, 86, 88, 93.

\section{Microphrys bicornutus (Latreille, 1825)}

Distribution: Western Atlantic - North Carolina to southern Florida, Bermuda, Gulf of Mexico, Antilles, Central America, Venezuela and Brazil (Fernando de Noronha, and from Maranhão to Rio Grande do Sul).

Habitat: Very common on coral reefs and in almost all shallow marine habitats. Almost always covered with anemones, algae or sponges.

Material examined: Stations 23, 34, 36, 48, 56, 61, 66, 73, 74, 85.

\section{Microphrys interruptus Rathbun, 1920}

Distribution: Western Atlantic - Antilles and Brazil (Fernando de Noronha, and from Piauí to Alagoas).

Habitat: Bottoms composed of calcareous algae and sand, and rocky reefs. Shallow waters to $50 \mathrm{~m}$.

Material examined: Station 39, 75.

\section{Mithraculus forceps (A. Milne-Edwards, 1875)}

Distribution: Western Atlantic- North Carolina to southern Florida, Gulf of Mexico, Antilles, Venezuela and Brazil (Fernando de Noronha and Rocas Atoll, and from Maranhão to São Paulo).

Habitat: Intertidal to $90 \mathrm{~m}$. On hard, fissured substrates along rocky beaches. Also on sandy, coral and algal bottoms, in addition to sponges.

Material examined: Stations 2, 3, 5, 6, 10, 15, 16, 19, 22, $23,28,29,32,33,34,35,36,37,39,40,45,47,54,56,63,68$, 69, 76, 80 .

\section{Mithrax hemphilli Rathbun, 1892}

Distribution: Western Atlantic - Florida, Antilles and Brazil (Rocas Atoll, and from Maranhão to Rio de Janeiro).

Habitat: Reefs and calcareous algae, under rocks and in Thalassia meadows. Intertidal to $60 \mathrm{~m}$.

Material examined: Stations 5, 6, 56, 60, 61, 63, 64, 69, 85, 88, 93.

\section{Pisidae Dana, 1851}

\section{Apiomithrax violaceus (A. Milne-Edwards, 1868)}

Distribution: Western Atlantic - Brazil (from Paraíba to Rio Grande do Sul). Eastern Atlantic - Cape Verde islands and from Cabo Branco (Azores) to Angola. Mid-Atlantic - Ascension Island.

Habitat: Sandy and muddy bottoms. Shallow waters to $50 \mathrm{~m}$.

Material examined: Stations 18, 51, 60, 76, 81.

\section{Chorinus heros (Herbst, 1790)}

Distribution: Western Atlantic - Bermuda, Florida, Gulf of Mexico, Antilles, Venezuela and Brazil (from Ceará to Bahia).

Habitat: Shallow waters to $50 \mathrm{~m}$. Sandy, rocky and shell bottoms, and mainly in corals.

Material examined: Stations 18, 29, 51, 68, 73.

\section{Notolopas brasiliensis Miers, 1886}

Distribution: Western Atlantic - Colombia, Venezuela and Brazil (from Amapá to São Paulo).

Habitat: Muddy and calcareous algae bottoms, occasionally on sand and shell. Intertidal to $30 \mathrm{~m}$.

Material examined: Stations 68, 73.

\section{Tichidae Dana, 1851}

\section{Picroceroides tubularis Miers, 1886}

Distribution: Western Atlantic - Florida, Gulf of Mexico, 
Antilles and Brazil (from Maranhão to Espírito Santo).

Habitat: Preference for calcareous algae bottoms, and depths from 20 to $90 \mathrm{~m}$.

Material examined: Stations 29, 60, 61, 62.

Pitho Iherminieri (Schramm, 1867)

Distribution: Western Atlantic - From North Carolina to Florida, Gulf of Mexico, Antilles and Brazil (Fernando de Noronha, and from Pará to São Paulo).

Habitat: Muddy, sandy, broken-shell, rocky and coral bottoms. Shallow waters to $30 \mathrm{~m}$, exceptionally to $200 \mathrm{~m}$.

Material examined: Stations 50, 60, 66, 74, 75, 77.

Tyche potiguara Garth, 1952

Distribution: Western Atlantic - Brazil (from Rio Grande do Norte to Alagoas).

Habitat: On bottoms of calcareous algae and broken shells, and in waters 25 to $70 \mathrm{~m}$ deep.

Material examined: Stations 16, 47, 56, 60, 68.

\section{Parthenopidae MacLeay, 1838}

\section{Heterocrypta granulata (Gibbes, 1850)}

Distribution: Western Atlantic - From Massachusetts to Florida, Gulf of Mexico, Antilles and Brazil (from Ceará to Paraná).

Habitat: Sandy, shell and gravel bottoms, where its shape and coloration provide excellent camouflage. Occasionally on rocks and corals. Shallow waters to $140 \mathrm{~m}$.

Material examined: Stations 42, 47.

\section{Portunidae Rafinesque, 1815}

\section{Cronius ruber (Lamarck, 1818)}

Distribution: Western Atlantic - North Carolina to southern Florida, Gulf of Mexico, Central America, Antilles, northern South America and Brazil (from Amapá to Rio Grande do Sul). Eastern Atlantic - from Senegal to Angola. Eastern Pacific - from California to Peru and the Galápagos Islands.

Habitat: Sandy beaches, and rocky and gravelly areas. Shallow waters to $110 \mathrm{~m}$.

Material examined: Stations 2, 15, 45, 51, 81.

\section{Cronius tumidulus (Stimpson, 1871)}

Distribution: Western Atlantic - Bermuda, Florida, Gulf of Mexico, Antilles, Guianas and Brazil (from Pará to São Paulo).

Habitat: On sandy, coral and rocky bottoms, and also on algae-covered bottoms. Shallow waters to $75 \mathrm{~m}$.

Material examined: Stations 1, 2, 6, 12, 13, 15, 18, 19, $20,21,29,32,37,46,47,48,49,54,56,71,80,81,83,84,86$, 87, 88, 90.

\section{Portunus anceps (Saussure, 1858)}

Distribution: Western Atlantic - North Carolina, Bermuda, Florida, Gulf of Mexico, Antilles and Brazil (from Amapá to Rio de Janeiro).
Habitat: Mainly on sandy, muddy, shell and hard-substrate bottoms. Often on algae-covered bottoms. Usually buried in sand.

Material examined: Stations 1, 16, 18, 20, 36, 42, 75, 85.

\section{Portunus ordwayi (Stimpson, 1860)}

Distribution: Western Atlantic - Massachusetts to Florida, Gulf of Mexico, Antilles, Venezuela, Guianas and Brazil (Fernando de Noronha, and from Amapá to Rio Grande do Sul).

Habitat: On substrates of sand, gravel, broken shells and corals.

Material examined: Stations 13, 56.

\section{Portunus sayi (Gibbes, 1850)}

Distribution: Western Atlantic - Nova Scotia $\left(43^{\circ} \mathrm{N}\right)$ to Florida, Gulf of Mexico, Guianas and Brazil (Paraíba to Bahia). Habitat: Usually in floating masses of algae.

Material examined: Station 2.

\section{Xanthidae MacLeay, 1838}

\section{Actaea acantha (H. Milne Edwards, 1834)}

Distribution: Western Atlantic - Florida, Gulf of Mexico, Antilles and Brazil (Fernando de Noronha and Rocas Atoll, and from Amapá to Pernambuco).

Habitat: Sandy, muddy, shell and coral bottoms. Depths to $25 \mathrm{~m}$.

Material examined: Stations 65, 86.

\section{Garthiope spinipes (A. Milne-Edwards, 1880)}

Distribution: Western Atlantic - Bermuda, Florida, Gulf of Mexico, Venezuela and Brazil (from Amapá to Espírito Santo).

Habitat: Sandy bottoms, coral reefs, and sponges. Intertidal to $60 \mathrm{~m}$.

Material examined: Stations 5, 6, 29, 34, 47, 48, 54, 61, 64, 81, 93

\section{Melybia thalamita Stimpson, 1871}

Distribution: Western Atlantic - Florida, Gulf of Mexico, Antilles, northern South America and Brazil (from Amapá to São Paulo).

Habitat: In corals and on sandy, rocky and broken-shell bottoms. Depths to $200 \mathrm{~m}$.

Material examined: Stations 5, 29, 31, 32, 46, 47, 56, 90.

\section{Micropanope lobifrons A. Milne-Edwards, 1880}

Distribution: Western Atlantic - Florida, Antilles, Central America (Panama) and Brazil (Paraíba).

Habitat: Sandy bottoms and among algae. Usually between 60 and $340 \mathrm{~m}$, but can be found at lower depths.

Material examined: Station 47.

\section{Micropanope nuttingi (Rathbun, 1898)}

Distribution: Western Atlantic - North Carolina, Florida, Gulf of Mexico, Antilles and Brazil (from Amapá to São Paulo). Habitat: Rocky, coral, sandy and broken-shell bottoms. Also on bottoms of Porites and Halimede. Shallow waters to $180 \mathrm{~m}$. 
Material examined: Stations 6, 22, 34, 35, 36, 38, 39, 56, 60, 75, 81, 84, 86, 90.

\section{Micropanope pusilla A. Milne-Edwards, 1880}

Distribution: Western Atlantic - Florida, Gulf of Mexico, Antilles and Brazil (from Pará to Paraíba).

Habitat: Sandy, gravel, broken-shell and coral bottoms.

From 30 to $310 \mathrm{~m}$.

Material examined: Stations 3, 5, 31, 38, 45, 47.

Micropanope sculptipes Stimpson, 1871

Distribution: Western Atlantic - North and South Carolina, Florida, Gulf of Mexico, Antilles and Brazil (from Amapá to Rio de Janeiro).

Habitat: Sandy, gravel, coral and broken-shell bottoms. Depths from 10 to $310 \mathrm{~m}$.

Material examined: Stations 62, 64, 68.

\section{Paractaea rufopunctata nodosa (Stimpson, 1860)}

Distribution: Western Atlantic - North Carolina, Florida, Gulf of Mexico, Antilles, northern South America, Brazil (from Amapá to Rio de Janeiro) and Uruguay. Mid-Atlantic - Ascension Island.

Habitat: In corals and bottoms of sand, shell gravel, rocks and occasionally mud. Intertidal to $220 \mathrm{~m}$.

Material examined: Stations 3, 8, 13, 21, 31, 32, 33, 35, $37,39,45,47,54,56,60,61,64,69,76,80,86,88$.

\section{Pilumnoides coelhoi Guinot \& Macpherson, 1987}

Distribution: Western Atlantic - Brazil (from Bahia to Santa Catarina).

Habitat: Shallow waters to $30 \mathrm{~m}$. On sandy bottoms or among algae.

Material examined: Station 90.

\section{Pilumnus diomedeae Rathbun, 1894}

Distribution: Western Atlantic - Gulf of Mexico, Antilles and Brazil (Amapá to Rio Grande do Sul).

Habitat: Muddy and coral bottoms. From 20 to $340 \mathrm{~m}$ depth.

Material examined: Stations 40, 53, 93.

\section{Pilumnus reticulatus Stimpson, 1860}

Distribution: Western Atlantic - Antilles, Central America, northern South America, Brazil (from Pará to Rio Grande do Sul), Uruguay and Argentina.

Habitat: Sandy and shell bottoms. Intertidal to $75 \mathrm{~m}$.

Material examined: Stations 9, 88.

\section{Pilumnus spinosissimus Rathbun, 1898}

Distribution: Western Atlantic - Florida, Gulf of Mexico, Antilles and Brazil (Rio Grande do Norte to Santa Catarina).

Habitat: On sandy, rocky and, mainly, coral substrates. Depths from 5 to $20 \mathrm{~m}$.

Material examined: Stations 9, 15, 20, 22, 23, 40, 49, 51, 53, 81, 83, 86, 89, 90.

Platypodiella spectabilis (Herbst, 1794)
Distribution: Western Atlantic - Bermuda, Florida, Gulf of Mexico, Antilles, Venezuela and Brazil (Fernando de Noronha and Trindade Island, and from Rio Grande do Norte to Rio de Janeiro).

Habitat: Coral reefs and under rocks. Shallow depths of 5 to $15 \mathrm{~m}$

Material examined: Stations 45, 55, 62, 64, 68, 85.

Xanthodius denticulatus (White, 1848)

Distribution: Western Atlantic - Bermuda, Florida, Gulf of Mexico, Antilles, Venezuela and Brazil (São Pedro and São Paulo Rocks, and from Ceará to Bahia).

Habitat: Tidepools, coral reefs and under rocks. Intertidal to $15 \mathrm{~m}$.

Material examined: Stations 35, 66, 69.

\section{Goneplacidae MacLeay, 1838}

\section{Cyrtoplax spinidentata (Benedict, 1892)}

Distribution: Western Atlantic - Antilles and Brazil (from Pernambuco to Rio Grande do Sul).

Habitat: Muddy bottoms, occasionally in sand or among algae. Shallow waters to $150 \mathrm{~m}$.

Material examined: Station 5.

\section{Nanoplax xanthiformis (A. Milne-Edwards, 1880)}

Distribution: Western Atlantic - North Carolina to Florida, Gulf of Mexico, Antilles, northern South America and Brazil (from Amapá to Rio de Janeiro).

Habitat: Sandy, broken-shell, muddy and coral bottoms. Depths from 10 to $330 \mathrm{~m}$.

Material examined: Stations: $28-61$.

Out of 93 stations established for Project Algas, 3 (24, $25,26)$ were not sampled, and at 12 stations $(14,17,41,44,58$, $59,70,72,78,79,91,92)$ no brachyurans were collected.

\section{DISCUSSION}

The richest stations in species were: numbers 56 (13 species), 60 and 85 (10 species each). The species found most often were Mithraculus forceps (29 stations), Cronius tumidulus (28 stations) and Paractaea rufopunctata nodosa (22 stations) (Tab I).

Calcareous algae, coralligenous, and organogenic bottoms in the tropical region of the Western Atlantic occur north of the Antilles, north of South America, and off northeastern Brazil. Northward along the Brazilian coast in the direction of Pará, and southward toward São Paulo, these bottom types occur farther and farther off the coast until they completely disappear (KempF 1970, Coutinho \& KempF 1973). These types of substrates occur widely off the coast of Paraíba.

As was to be expected, the largest group (41.6\%) of the species collected in Project Algas is tropical and of Caribbean origin. These species take advantage of the high temperatures caused by the Brazil Current, generally reaching southward as far as Rio de Janeiro, although they may also reach to Rio 
Table I. Oceanographic data and species collected in each station of the Project Algas.

\begin{tabular}{|c|c|c|c|c|c|c|}
\hline Stations & Date & Position & $\begin{array}{l}\text { Depth } \\
(\mathrm{m})\end{array}$ & $\begin{array}{c}\text { Temp. } \\
\left({ }^{\circ} \mathrm{C}\right)\end{array}$ & Species & $\begin{array}{l}\text { Number } \\
\text { of species }\end{array}$ \\
\hline 1 & $21 / 1 / 1981$ & $7^{\circ} 34^{\prime} \mathrm{S}, 34^{\circ} 45^{\prime} \mathrm{W}$ & 11 & 28,30 & Cronius tumidulus, Portunus anceps & 2 \\
\hline 2 & $21 / 4 / 1981$ & $7^{\circ} 34^{\prime} \mathrm{S}, 34^{\circ} 42^{\prime} \mathrm{W}$ & 20 & 28,00 & $\begin{array}{l}\text { Symethis variolosa, Cryptosoma balgueri, Macrocoeloma. } \\
\text { septemspinosum, Mithraculus forceps, Cronius ruber, C. tumidulus, } \\
\text { Portunus sayi }\end{array}$ & 7 \\
\hline 3 & $22 / 1 / 1981$ & $7^{\circ} 34^{\prime} \mathrm{S}, 34^{\circ} 39^{\prime} \mathrm{W}$ & 26 & 27,62 & $\begin{array}{l}\text { Macrocoeloma septemspinosum, Mithraculus forceps, Micropanope } \\
\text { pusilla, Paractaea rufopunctata nodosa }\end{array}$ & 4 \\
\hline 4 & $22 / 1 / 1981$ & $7^{\circ} 34^{\prime} \mathrm{S}, 34^{\circ} 36^{\prime} \mathrm{W}$ & 33 & 27,82 & Calappa ocellata, Goniopsis cruentata & 2 \\
\hline 5 & $22 / 1 / 1981$ & $7^{\circ} 31^{\prime} \mathrm{S}, 34^{\circ} 31^{\prime} \mathrm{W}$ & 34 & 27,90 & $\begin{array}{l}\text { Microphrys antillensis, Mithraculus forceps, Mithrax hemphilli, } \\
\text { Garthiope spinipes, Melybia thalamita, Micropanope pusilla, Cyrtoplax } \\
\text { spinidentata }\end{array}$ & 7 \\
\hline 6 & $23 / 1 / 1981$ & $7^{\circ} 31^{\prime} \mathrm{S}, 34^{\circ} 39^{\prime} \mathrm{W}$ & 24 & 27,80 & $\begin{array}{l}\text { Symethis variolosa, Cronius tumidulus, Garthiope spinipes, } \\
\text { Micropanope nuttingi }\end{array}$ & 4 \\
\hline 7 & $23 / 1 / 1981$ & $7^{\circ} 31^{\prime} \mathrm{S}, 34^{\circ} 42^{\prime} \mathrm{W}$ & 16 & 28,80 & Symethis variolosa & 1 \\
\hline 8 & $05 / 5 / 1981$ & $7^{\circ} 31^{\prime} \mathrm{S}, 34^{\circ} 45^{\prime} \mathrm{W}$ & 10 & 28,40 & Paractaea rufopunctata. nodosa & 1 \\
\hline 9 & $05 / 5 / 1981$ & $7^{\circ} 28^{\prime} \mathrm{S}, 34^{\circ} 44^{\prime} \mathrm{W}$ & 10 & 28,50 & Pilumnus reticulatus, $P$. spinosissimus & 2 \\
\hline 10 & $05 / 5 / 1981$ & $7^{\circ} 28^{\prime} \mathrm{S}, 34^{\circ} 40^{\prime} \mathrm{W}$ & 14 & 28,52 & Mithraculus forceps & 1 \\
\hline 11 & $05 / 5 / 1981$ & $7^{\circ} 28^{\prime} \mathrm{S}, 34^{\circ} 37^{\prime} \mathrm{W}$ & 24 & 28,32 & Speloeophorus. elevatus & 1 \\
\hline 12 & $06 / 5 / 1981$ & $7^{\circ} 28^{\prime} \mathrm{S}, 34^{\circ} 34^{\prime} \mathrm{W}$ & 30 & 28,20 & $\begin{array}{l}\text { Calappa gallus, Podochela brasiliensis, Leptopisa setirostris, } \\
\text { Macrocoeloma trispinosum, Crorius tumidulus }\end{array}$ & 5 \\
\hline 13 & $06 / 5 / 1981$ & $7^{\circ} 25^{\prime} \mathrm{S}, 34^{\circ} 34^{\prime} \mathrm{W}$ & 30 & 28,24 & Cronius tumidulus, Portunus ordwayi, Paractaea rufopunctata nodosa & 3 \\
\hline 15 & $07 / 5 / 1981$ & $7^{\circ} 25^{\prime} \mathrm{S}, 34^{\circ} 34^{\prime} \mathrm{W}$ & 14 & 28,20 & $\begin{array}{l}\text { Mithraculus forceps, Crorius ruber, C. tumidulus, Pilumnus } \\
\text { spinosissimus }\end{array}$ & 4 \\
\hline 16 & $07 / 5 / 1981$ & $7^{\circ} 25^{\prime} \mathrm{S}, 34^{\circ} 43^{\prime} \mathrm{W}$ & 10 & 28,30 & Symethis variolosa, Mithraculus forceps, Tiche potiguara & 3 \\
\hline 18 & $13 / 5 / 1981$ & $7^{\circ} 18^{\prime} \mathrm{S}, 34^{\circ} 36^{\prime} \mathrm{W}$ & 14 & 27,30 & $\begin{array}{l}\text { Acanthonyx dissimulatus, Podochela riisei, Apiomithrax violaceus, } \\
\text { Chorinus heros, Cronius tumidulus, Portunus anceps }\end{array}$ & 6 \\
\hline 19 & $13 / 5 / 1981$ & $7^{\circ} 21^{\prime} \mathrm{S}, 34^{\circ} 38^{\prime} \mathrm{W}$ & 16 & 27,50 & Mithraculus forceps, Cronius tumidulus & 2 \\
\hline 20 & $13 / 5 / 1981$ & $7^{\circ} 21^{\prime} \mathrm{S}, 34^{\circ} 38^{\prime} \mathrm{W}$ & 30 & 27,50 & $\begin{array}{l}\text { Microphrys antillensis, Cronius tumidulus, Portunus anceps, Pilumnus } \\
\text { spinosissimus }\end{array}$ & 4 \\
\hline 21 & $14 / 5 / 1981$ & $7^{\circ} 18^{\prime} \mathrm{S}, 34^{\circ} 33^{\prime} \mathrm{W}$ & 30 & 27,50 & $\begin{array}{l}\text { Microphrys antillensis, Cronius tumidulus, Paractaea rufopunctata } \\
\text { nodosa }\end{array}$ & 3 \\
\hline 22 & $14 / 5 / 1981$ & $7^{\circ} 21^{\prime} \mathrm{S}, 34^{\circ} 41^{\prime} \mathrm{W}$ & 28 & 27,50 & Mithraculus forceps, Micropanope nuttingi, Pilumnus spinosissimus & 3 \\
\hline 23 & $14 / 5 / 1981$ & $7^{\circ} 18^{\prime} \mathrm{S}, 34^{\circ} 00^{\prime} \mathrm{W}$ & 18 & 27,50 & Microphrys bicornutus, Mithraculus forceps, Pilumnus spinosissimus & 3 \\
\hline 27 & $13 / 4 / 1981$ & $7^{\circ} 15^{\prime} \mathrm{S}, 34^{\circ} 42^{\prime} \mathrm{W}$ & 16 & 28,10 & Macrocoeloma laevigatum & 1 \\
\hline 28 & $02 / 4 / 1981$ & $7^{\circ} 15^{\prime} \mathrm{S}, 37^{\circ} 39^{\prime} \mathrm{W}$ & 22 & 28,30 & Mithraculus forceps, Nanoplax xanthiformis & 2 \\
\hline 29 & $02 / 4 / 1981$ & $7^{\circ} 15^{\prime} \mathrm{S}, 34^{\circ} 36^{\prime} \mathrm{W}$ & 28 & 28,00 & $\begin{array}{l}\text { Symethis variolosa, Calappa gallus, Leptopisa setirostris, Mithraculus } \\
\text { forceps, Chorinus heros, Picroceroides tubularis, Cronius tumidulus, } \\
\text { Garthiope spinipes, Melybia thalamita }\end{array}$ & 9 \\
\hline 30 & $01 / 4 / 1981$ & $7^{\circ} 15^{\prime} \mathrm{S}, 34^{\circ} 33^{\prime} \mathrm{W}$ & 35 & 28,12 & Moreiradromia antillensis & 1 \\
\hline 31 & $01 / 4 / 1981$ & $7^{\circ} 12^{\prime} \mathrm{S}, 34^{\circ} 36^{\prime} \mathrm{W}$ & 26 & 28,10 & $\begin{array}{l}\text { Calappa gallus, C. ocellata, Microphrys antillensis, Melybia thalamita, } \\
\text { Micropanope pusilla, Paractaea rufopunctata nodosa }\end{array}$ & 6 \\
\hline 32 & $01 / 4 / 1981$ & $7^{\circ} 12^{\prime} \mathrm{S}, 34^{\circ} 39^{\prime} \mathrm{W}$ & 20 & 28,10 & $\begin{array}{l}\text { Calappa gallus, Microphrys antillensis, Mithraculus forceps, Cronius } \\
\text { tumidulus, Melybia thalamita, Paractaea rufopunctata nodosa }\end{array}$ & 6 \\
\hline 33 & $27 / 3 / 1981$ & $7^{\circ} 13^{\prime} \mathrm{S}, 34^{\circ} 42^{\prime} \mathrm{W}$ & 20 & 28,00 & $\begin{array}{l}\text { Calappa gallus, Speloeophorus elevatus, Podochela algicola, } \\
\text { Macrocoeloma laevigatum, Microphrys antillensis, Mithraculus forceps, } \\
\text { Paractaea rufopunctata nodosa }\end{array}$ & 7 \\
\hline 34 & $27 / 3 / 1981$ & $7^{\circ} 13^{\prime} \mathrm{S}, 34^{\circ} 45^{\prime} \mathrm{W}$ & 10 & 28,10 & $\begin{array}{l}\text { Macrocoeloma laevigatum, Microphrys bicornutus, Mithraculus } \\
\text { forceps, Garthiope spinipes, Micropanope nuttingi }\end{array}$ & 5 \\
\hline
\end{tabular}


Table I. Continued.

\begin{tabular}{|c|c|c|c|c|c|c|}
\hline Stations & Date & Position & $\begin{array}{l}\text { Depth } \\
(\mathrm{m})\end{array}$ & $\begin{array}{l}\text { Temp. } \\
\left({ }^{\circ} \mathrm{C}\right)\end{array}$ & Species & $\begin{array}{l}\text { Number } \\
\text { of species }\end{array}$ \\
\hline 35 & $26 / 3 / 1981$ & $7^{\circ} 10^{\prime} \mathrm{S}, 34^{\circ} 45^{\prime} \mathrm{W}$ & 10 & 28,70 & $\begin{array}{l}\text { Macroceloma laevigatum, Microphrys antillensis, Mithraculus forceps, } \\
\text { Micropanope nuttingi, Paractaea rufopunctata nodosa, Xanthodius } \\
\text { denticulatus }\end{array}$ & 6 \\
\hline 36 & $26 / 3 / 1981$ & $7^{\circ} 10^{\prime} \mathrm{S}, 34^{\circ} 42^{\prime} \mathrm{W}$ & 16 & 28,00 & $\begin{array}{l}\text { Symethis variolosa, Macrocoeloma laevigatum, Microphrys bicornutus, } \\
\text { Mithraculus forceps, Portunus anceps, Micropanope nuttingi }\end{array}$ & 6 \\
\hline 37 & $26 / 3 / 1981$ & $7^{\circ} 10^{\prime} \mathrm{S}, 34^{\circ} 38^{\prime} \mathrm{W}$ & 25 & 27,90 & $\begin{array}{l}\text { Symethis variolosa, lliacantha sparsa, Micropanope laevigatum, } \\
\text { Mithraculus forceps, Cronius tumidulus, Paractaea rufopunctata } \\
\text { nodosa }\end{array}$ & 6 \\
\hline 38 & $25 / 5 / 1981$ & $7^{\circ} 37^{\prime} \mathrm{S}, 34^{\circ} 37^{\prime} \mathrm{W}$ & 27 & 28,00 & $\begin{array}{l}\text { Symethis variolosa, Microphrys antillensis, Micropanope nuttingi, M. } \\
\text { pusilla }\end{array}$ & 4 \\
\hline 39 & $20 / 3 / 1981$ & $7^{\circ} 07^{\prime} \mathrm{S}, 34^{\circ} 40^{\prime} \mathrm{W}$ & 27 & 27,80 & $\begin{array}{l}\text { Microphrys antillensis, M. interruptus, Mithraculus forceps, } \\
\text { Micropanope nuttingi, Paractaea rufopunctata nodosa }\end{array}$ & 5 \\
\hline 40 & $19 / 3 / 1981$ & $7^{\circ} 07^{\prime} \mathrm{S}, 34^{\circ} 43^{\prime} \mathrm{W}$ & 17 & 27,00 & Mithraculus forceps, Pilumnus diomedeae, P. spinosissimus & 3 \\
\hline 42 & $05 / 2 / 1981$ & $7^{\circ} 07^{\prime} \mathrm{S}, 34^{\circ} 47^{\prime} \mathrm{W}$ & 10 & 28,00 & Podochela gracilipes, Heterocrypta granulata, Portunus anceps & 3 \\
\hline 43 & $16 / 2 / 1981$ & $7^{\circ} 04^{\prime} \mathrm{S}, 34^{\circ} 44^{\prime} \mathrm{W}$ & 16 & 28,40 & Symethis variolosa & 1 \\
\hline 45 & $17 / 2 / 1981$ & $7^{\circ} 04^{\prime} \mathrm{S}, 34^{\circ} 38^{\prime} \mathrm{W}$ & 26 & 27,80 & $\begin{array}{l}\text { Symethis variolosa, Podochela algicola, P. riisei, Mithraculus forceps, } \\
\text { Cronius ruber, Micropanope pusilla, Paractaea rufopunctata nodosa, } \\
\text { Platypodiella spectabilis }\end{array}$ & 8 \\
\hline 46 & $17 / 2 / 1981$ & $7^{\circ} 04^{\prime} \mathrm{S}, 34^{\circ} 36^{\prime} \mathrm{W}$ & 34 & 27,80 & Podochela algicola, Cronius tumidulus, Melybia thalamita & 3 \\
\hline 47 & $13 / 2 / 1981$ & $7^{\circ} 01^{\prime} \mathrm{S}, 34^{\circ} 30^{\prime} \mathrm{W}$ & 26 & 28,10 & $\begin{array}{l}\text { Symethis variolosa, Ebalia stimpsoni, Speloeophorus nodosus, } \\
\text { Leptopisa. setirostris, Mithraculus forceps, Tiche potiguara, } \\
\text { Heterocrypta granulata, Cronius tumidulus, Garthiope spinipes, } \\
\text { Melybia thalamita, Micropanope lobifrons, Paractaea rufopunctata } \\
\text { nodosa }\end{array}$ & 12 \\
\hline 48 & $13 / 2 / 1981$ & $7^{\circ} 01 ' \mathrm{~S}, 34^{\circ} 41^{\prime} \mathrm{W}$ & 24 & 28,20 & $\begin{array}{l}\text { Aepinus septemspinosus, Microphrys bicornutus, Cronius tumidulus, } \\
\text { Garthiope spinipes }\end{array}$ & 4 \\
\hline 49 & $06 / 2 / 1981$ & $7^{\circ} 01^{\prime} \mathrm{S}, 34^{\circ} 45^{\prime} \mathrm{W}$ & 16 & 28,10 & Cronius tumidulus, Pilumnus spinosissimus & 2 \\
\hline 50 & $05 / 2 / 1981$ & $7^{\circ} 01 ' S, 34^{\circ} 47^{\prime} \mathrm{W}$ & 11 & 28,00 & Podochela gracilipes, Pitho Iherminieri & 2 \\
\hline 51 & $05 / 2 / 1981$ & $6^{\circ} 58^{\prime} \mathrm{S}, 34^{\circ} 46^{\prime} \mathrm{W}$ & 14 & 27,90 & $\begin{array}{l}\text { Acanthonyx dissimulatus, Apiomithrax violaceus, Chorinus heros, } \\
\text { Cronius ruber, Pilumnus spinosissimus }\end{array}$ & 5 \\
\hline 52 & $06 / 2 / 1981$ & $6^{\circ} 58^{\prime} \mathrm{S}, 34^{\circ} 44^{\prime} \mathrm{W}$ & 20 & 28,10 & Aepinus septemspinosus & 1 \\
\hline 53 & $12 / 2 / 1981$ & $6^{\circ} 57^{\prime} \mathrm{S}, 34^{\circ} 41^{\prime} \mathrm{W}$ & 26 & 28,04 & $\begin{array}{l}\text { Microphrys antillensis, Ethusa americana, Aepinus septemspinosus, } \\
\text { Podochela algicola, Moreiradromia antillensis, Pilumnus diomedeae, P. } \\
\text { spinosissimus }\end{array}$ & 7 \\
\hline 54 & $12 / 2 / 1981$ & $6^{\circ} 57^{\prime} \mathrm{S}, 34^{\circ} 38^{\prime} \mathrm{W}$ & 30 & 28,10 & $\begin{array}{l}\text { Mithraculus forceps, Cronius tumidulus, Garthiope spinipes, Paractaea } \\
\text { rufopunctata nodosa }\end{array}$ & 4 \\
\hline 55 & $11 / 2 / 1981$ & $6^{\circ} 55^{\prime} \mathrm{S}, 34^{\circ} 40^{\prime} \mathrm{W}$ & 28 & 28,10 & Platypodiella spectabilis & 1 \\
\hline 56 & $11 / 2 / 1981$ & $6^{\circ} 55^{\prime} \mathrm{S}, 34^{\circ} 43^{\prime} \mathrm{W}$ & 21 & 27,96 & $\begin{array}{l}\text { Iliacantha sparsa, Persephona punctata, Epialtoides rostratus, } \\
\text { Macrocoeloma laevigatum, Microphrys bicornutus, Mithraculus } \\
\text { forceps, Mithrax emphilli, Tiche potiguara, Cronius tumidulus, } \\
\text { Portunus ordwayi, Melybia thalamita, Micropanope nuttingi, } \\
\text { Paractaea rufopunctata nodosa }\end{array}$ & 13 \\
\hline 57 & $06 / 2 / 1981$ & $6^{\circ} 55^{\prime} \mathrm{S}, 34^{\circ} 46^{\prime} \mathrm{W}$ & 18 & 28,10 & Podochela brasiliensis & 1 \\
\hline 60 & $19 / 2 / 1981$ & $6^{\circ} 52^{\prime} \mathrm{S}, 34^{\circ} 46^{\prime} \mathrm{W}$ & 18 & 28,00 & $\begin{array}{l}\text { Aepinus septemspinosus, Euprognatha acuta, Microphrys antillensis, } \\
\text { Mithrax hemphilli, Apiomithrax violaceus, Picroceroides tubularis, Pitho } \\
\text { Iherminieri, Tiche potiguara, Micropanope nuttingi, Paractaea } \\
\text { rufopunctata nodosa }\end{array}$ & 10 \\
\hline 61 & $20 / 2 / 1981$ & $6^{\circ} 52^{\prime} \mathrm{S}, 34^{\circ} 42^{\prime} \mathrm{W}$ & 20 & 27,80 & $\begin{array}{l}\text { Calappa angusta, Speloeophorus elevatus, Microphrys antillensis, M. } \\
\text { bicornutus, Mithrax hemphilli, Picroceroides tubularis, Garthiope } \\
\text { spinipes, Paractaea rufopunctata nodosa, Nanoplax xanthiformis }\end{array}$ & 9 \\
\hline
\end{tabular}


Table I. Continued.

\begin{tabular}{|c|c|c|c|c|c|c|}
\hline Stations & Date & Position & $\begin{array}{l}\text { Depth } \\
(\mathrm{m})\end{array}$ & $\begin{array}{l}\text { Temp. } \\
\left({ }^{\circ} \mathrm{C}\right)\end{array}$ & Species & $\begin{array}{l}\text { Number } \\
\text { of species }\end{array}$ \\
\hline 62 & $20 / 2 / 1981$ & $6^{\circ} 52^{\prime} \mathrm{S}, 34^{\circ} 40^{\prime} \mathrm{W}$ & 32 & 27,80 & $\begin{array}{l}\text { Lithadia vertiginosa, Picroceroides tubularis, Micropanope sculptipes, } \\
\text { Platypodiella spectabilis }\end{array}$ & 4 \\
\hline 63 & $11 / 3 / 1981$ & $6^{\circ} 50^{\prime} \mathrm{S}, 34^{\circ} 42^{\prime} \mathrm{W}$ & 30 & - & Mithraculus forceps, Mithrax hemphilli & 2 \\
\hline 64 & $11 / 3 / 1981$ & $6^{\circ} 50^{\prime} \mathrm{S}, 34^{\circ} 44^{\prime} \mathrm{W}$ & 26 & - & $\begin{array}{l}\text { Calappa gallus, Mithrax hemphilli, Garthiope spinipes, Micropanope } \\
\text { sculptipes, Paractaea rufopunctata nodosa, Platypodiella spectabilis }\end{array}$ & 6 \\
\hline 65 & $12 / 3 / 1981$ & $6^{\circ} 50^{\prime} \mathrm{S}, 34^{\circ} 47^{\prime} \mathrm{W}$ & 18 & - & Microphrys antillensis, Actaea acantha & 2 \\
\hline 66 & $12 / 3 / 1981$ & $6^{\circ} 50^{\prime} \mathrm{S}, 34^{\circ} 50^{\prime} \mathrm{W}$ & 10 & - & Microphrys bicornutus, Pitho Iherminieri, Xanthodius denticulatus & 3 \\
\hline 67 & $13 / 3 / 1981$ & $6^{\circ} 46^{\prime} \mathrm{S}, 34^{\circ} 53^{\prime} \mathrm{W}$ & 10 & 29,00 & Podochela brasiliensis, Macrocoeloma laevigatum & 2 \\
\hline 68 & $19 / 5 / 1981$ & $6^{\circ} 46^{\prime} \mathrm{S}, 34^{\circ} 50^{\prime} \mathrm{W}$ & 14 & 27,40 & $\begin{array}{l}\text { Microphrys antillensis, Mithraculus forceps, Chorinus heros, Notolopas } \\
\text { brasiliensis, Tiche potiguara, Micropanope sculptipes, Platypodiella } \\
\text { spectabilis }\end{array}$ & 7 \\
\hline 69 & $19 / 5 / 1981$ & $6^{\circ} 46^{\prime} \mathrm{S}, 34^{\circ} 47^{\prime} \mathrm{W}$ & 18 & 27,50 & $\begin{array}{l}\text { Microphrys antillensis, Mithraculus forceps, Mithrax emphilli, } \\
\text { Paractaea rufopunctata nodosa }\end{array}$ & 4 \\
\hline 71 & $20 / 5 / 1981$ & $6^{\circ} 43^{\prime} \mathrm{S}, 34^{\circ} 45^{\prime} \mathrm{W}$ & 22 & 27,30 & Cronius tumidulus & 1 \\
\hline 73 & $20 / 5 / 1981$ & $6^{\circ} 43^{\prime} \mathrm{S}, 34^{\circ} 51^{\prime} \mathrm{W}$ & 14 & 27,40 & Microphrys bicornutus, Chorinus heros, Notolopas brasiliensis & 3 \\
\hline 74 & $22 / 5 / 1981$ & $6^{\circ} 43^{\prime} \mathrm{S}, 34^{\circ} 54^{\prime} \mathrm{W}$ & 10 & 27,10 & Epialtus bituberculatus, Mithrax bicornutus, Pitho Iherminieri & 3 \\
\hline 75 & $22 / 5 / 1981$ & $6^{\circ} 40^{\prime} \mathrm{S}, 34^{\circ} 53^{\prime} \mathrm{W}$ & 10 & 27,20 & $\begin{array}{l}\text { Podochela riisei, Macrocoeloma laevigatum, Microphrys interruptus, } \\
\text { Pitho Iherminieri, Portunus anceps, Micropanope nuttingi }\end{array}$ & 6 \\
\hline 76 & $22 / 5 / 1981$ & $6^{\circ} 40^{\prime} \mathrm{S}, 34^{\circ} 52^{\prime} \mathrm{W}$ & 15 & 27,10 & $\begin{array}{l}\text { Lithadia brasiliensis, Speloeophorus nodosus, Acanthonyx } \\
\text { dissimulatus, Podochela riisei, Microphrys antillensis, Mithraculus } \\
\text { forceps, Apiomithrax violaceus, Paractaea rufopunctata nodosa }\end{array}$ & 8 \\
\hline 77 & $28 / 5 / 1981$ & $6^{\circ} 39^{\prime} \mathrm{S}, 34^{\circ} 49^{\prime} \mathrm{W}$ & 20 & 27,10 & Pitho Iherminieri & 1 \\
\hline 80 & $02 / 6 / 1981$ & $6^{\circ} 37^{\prime} \mathrm{S}, 34^{\circ} 51^{\prime} \mathrm{W}$ & 20 & 27,00 & $\begin{array}{l}\text { Symethis variolosa, Mithraculus forceps, Cronius tumidulus, Paractaea } \\
\text { rufopunctata nodosa }\end{array}$ & 4 \\
\hline 81 & $02 / 6 / 1981$ & $6^{\circ} 37^{\prime} \mathrm{S}, 34^{\circ} 54^{\prime} \mathrm{W}$ & 12 & 27,00 & $\begin{array}{l}\text { Acanthonyx dissimulatus, Apiomithrax violaceus, Cronius ruber, C. } \\
\text { tumidulus, Garthiope spinipes, Micropanope nuttingi, Pilumnus } \\
\text { spinosissimus }\end{array}$ & 7 \\
\hline 82 & 03/6/1981 & $6^{\circ} 37^{\prime} \mathrm{S}, 34^{\circ} 57^{\prime} \mathrm{W}$ & 12 & 26,70 & Calappa angusta, Ebalia stimpsoni & 2 \\
\hline 83 & $03 / 6 / 1981$ & $6^{\circ} 33^{\prime} \mathrm{S}, 34^{\circ} 57^{\prime} \mathrm{W}$ & 12 & 27,10 & Cronius tumidulus, Pilumnus spinosissimus & 2 \\
\hline 84 & 03/6/1981 & $6^{\circ} 33^{\prime} \mathrm{S}, 34^{\circ} 54^{\prime} \mathrm{W}$ & 14 & 27,20 & Cronius tumidulus, Micropanope nuttingi & 2 \\
\hline 85 & $04 / 6 / 1981$ & $6^{\circ} 33^{\prime} \mathrm{S}, 34^{\circ} 51^{\prime} \mathrm{W}$ & 20 & 27,00 & $\begin{array}{l}\text { Symethis variolosa, Lithadia brasiliensis, Speloeophorus nodosus, } \\
\text { Podochela riisei, Macrocoeloma laevigatum, Macrocoeloma } \\
\text { septemspinosum, Microphrys bicornutus, Mithrax hemphilli, Portunus } \\
\text { anceps, Platypodiella spectabilis }\end{array}$ & 10 \\
\hline 86 & $04 / 6 / 1981$ & $6^{\circ} 33^{\prime} \mathrm{S}, 34^{\circ} 47^{\prime} \mathrm{W}$ & 26 & 27,40 & $\begin{array}{l}\text { Macrocoeloma trispinosum, Microphrys antillensis, Cronius tumidulus, } \\
\text { Actaea acantha, Micropanope nuttingi, Paractaea rufopunctata } \\
\text { nodosa, Pilumnus spinosissimus }\end{array}$ & 7 \\
\hline 87 & 04/6/1981 & $6^{\circ} 29^{\prime} \mathrm{S}, 34^{\circ} 48^{\prime} \mathrm{W}$ & 30 & 27,90 & Cronius tumidulus & 1 \\
\hline 88 & $05 / 6 / 1981$ & $6^{\circ} 29^{\prime} \mathrm{S}, 34^{\circ} 51^{\prime} \mathrm{W}$ & 22 & 27,70 & $\begin{array}{l}\text { Microphrys antillensis, Macrocoeloma laevigatum, Moreiradromia } \\
\text { antillensis, Mithrax hemphilli, Cronius tumidulus, Paractaea } \\
\text { rufopunctata nodosa, Pilumnus reticulatus }\end{array}$ & 7 \\
\hline 89 & $10 / 6 / 1981$ & $6^{\circ} 29^{\prime} \mathrm{S}, 34^{\circ} 54^{\prime} \mathrm{W}$ & 17 & 27,10 & $\begin{array}{l}\text { Leptopisa setirostris, Macrocoeloma laevigatum, Pilumnus } \\
\text { spinosissimus }\end{array}$ & 3 \\
\hline 90 & $10 / 6 / 1981$ & $6^{\circ} 29^{\prime} \mathrm{S}, 34^{\circ} 57^{\prime} \mathrm{W}$ & 12 & 27,20 & $\begin{array}{l}\text { Acanthonyx dissimulatus, Macrocoeloma laevigatum, Cronius } \\
\text { tumidulus, Melybia thalamita, Micropanope nuttingi, Pilumnoides } \\
\text { coelhoi, Pilumnus spinosissimus }\end{array}$ & 7 \\
\hline 93 & $11 / 6 / 1981$ & $6^{\circ} 26^{\prime} \mathrm{S}, 34^{\circ} 52^{\prime} \mathrm{W}$ & 26 & 27,10 & $\begin{array}{l}\text { Microphrys antillensis, Mithrax hemphilli, Garthiope spinipes, } \\
\text { Pilumnus diomedeae }\end{array}$ & 4 \\
\hline
\end{tabular}

Revista Brasileira de Zoologia 22 (3): 796-805, setembro 2005 
Grande do Sul, depending on their degree of eurythermy or their ecological capabilities. Being thermophiles, along the coast of Paraíba they find waters of ideal temperature (mean $28^{\circ} \mathrm{C}$ ) for their survival. Four species $(0.66 \%)$ found off the Paraiban coast are, theoretically, Virginian species, of cold-temperate waters: Euprognatha acuta, Heterocrypta granulata, Portunus ordwayi and $P$. sayi. However, all of them occur off the coast of Virginia beyond depths of $180 \mathrm{~m}$, where the Gulf Stream, with its extremely warm waters, flows next to the outer continental shelf (Cerame-Vivas \& Gray 1966). Therefore these species should be considered tropical.

The so-called Carolinean or warm-temperate species were also found in great numbers (30\%). They normally extend as far south as the coast of Rio Grande do Sul, and sometimes reach the coast of Uruguay and northern Argentina.

Lithadia brasiliensis, L. vertiginosa, Acanthonyx dissimulatus, Epialtoides rostratus, Podochela brasiliensis, Tyche potiguara and Pilumnoides coelhoi form a group (11.66\%) of species endemic to Brazil. This relatively low rate of endemism demonstrates that the Paraíban coast, as long as Brachyura are concerned, did not undergo long periods of isolation.

Apiomithrax violaceus and Paractaea rufopunctata nodosa are the only species with an amphi-Atlantic distribution, making up 3.33\% of the species collected in this survey. The former has its northern limit at Paraíba, but also occurs in Africa (from the islands of Cape Verde to Angola and at Ascension Island). The latter is widely distributed in American waters, and also occurs in the mid-Atlantic (Ascension Island).

Two additional species, Ethusa americana and Cryptosoma balguerii, have an amphi-American distribution, with identical distributions on both sides of the Americas.

Calappa gallus and Cronius ruber are circumtropical, the former occurring in the Western and Eastern Atlantic and the Indo-Pacific, and the latter along both sides of the Atlantic and the Eastern Pacific.

\section{AKNOWLEDGMENTS}

The authors extend their thanks to Martin Lindsey
Christoffersen, Eraldo Sátiro Xavier Filho and Vanielle Cândido Barbosa, Departamento de Sistematica e Ecologia, Universidade Federal da Paraíba, for providing important information about Project Algas.

The author senior (GASM) thanks the National Council for the Development of Science and Technology (CNPq) for supporting this research through an ongoing grant 303224/ $87-8$.

\section{REFERENCES}

Cerame-Vivas, M.J. \& I.E. Gray. 1966. The distributional patterns of benthic invertebrates of the continental shelf off North Carolina. Ecology, Tempe, 47 (2): 260-270.

Coutinho, P.N. \& M. KempF. 1973. Plataforma continental do Norte, Nordeste e Leste do Brasil: amostras de fundo coletadas pelo Noc "Almirante Saldanha" (1968). Trabalhos Oceanográficos da Universidade Federal de Pernambuco, Recife, 12: 1-214.

Galil, B.S. \& P.F. Clark. 1996. A revision of Cryptosoma Brullé, 1837 and Cycloes de Haan, 1837 (Crustacea: Brachyura: Calappidae). Zoological Journal of the Linnean Society, London, 117: 175-204.

Guinot, D. \& M. TAVAREs. 2003. A new subfamilial arrangement for the Dromiidae de Haan, 1833, with diagnoses and descriptions of new genera and species (Crustacea, Decapoda, Brachyura). Zoosystema, Paris, 25 (1): 43-129.

Kempf, M. 1970. Notes on the benthic bionomy of the NE Brazilian shelf. Marine Biology, Berlin, 5 (3): 213-224.

Martin, J.W. \& G.E. Davis. 2001. An Updated Classification of the Recent Crustacea. Natural History Museum of Los Angeles County, Science Series, Los Angeles, 39: 1-124.

Melo, G.A.S. 1996. Manual de identificação dos Brachyura (caranguejos e siris) do litoral brasileiro. São Paulo, Plêiade, FAPESP, 603p.

Williams, A.B. \& C.A. Child. 1988. Comparison of some genera and species of box crabs (Brachyura: Calappidae), southwestern North Atlantic, with description of a new genus and species. Fishery Bulletin, Washington, 87 (1): 105-121.

Received in 18.I.2005; accepted in 17.VIII.2005. 